\title{
10
}

\section{Vertebrate fauna from Gua Sambangoala, Southeast Sulawesi}

\author{
Fakhri
}

\begin{abstract}
The purpose of this paper is to document the variety of fauna that the occupants of the Gua Sambangoala rockshelter interacted with and relied on for subsistence during the period 5500 to 3500 years ago. The faunal sample was recovered during excavation. Taxonomic frequencies and abundance were calculated using NISP (Number of Individual Specimens) and MNI (Minimum Number of Individuals). During the mid-Holocene period, the Sambangoala rockshelter inhabitants shared their environment with many endemic animals, including fish, toads/frogs, lizards, snakes, birds, bear cuscus, Sulawesi dwarf cuscus, bats, monkeys, rats, squirrels, civet cats, pig-deer (babirusa), Sulawesi warty pig (Sus celebensis) and Anoa water buffaloes. The larger of these animals were hunted by the forager inhabitants, whereas the smaller animals represented in the assemblage may have been taken by non-human predators. The identified fauna reflects surrounding environmental conditions that included open grasslands, valleys, karstic hills and wet rainforest habitat, suggesting that the mid-Holocene environment near the site was similar to today's.
\end{abstract}

Keywords: Gua Sambangoala, Southeast Sulawesi, mid-Holocene, faunal variety, faunal associations, environment

\section{Introduction}

Research funded by the Australian Research Council and led by Sue O'Connor between 2011 and 2014 documented 30 sites in an area spanning the north of Southeast Sulawesi Province and the northeastern lobe of South Sulawesi Province. The project's objectives included research into the time frame of the colonisation of Sulawesi by anatomically modern humans, their forager technology and adaptation to the environment, and the antiquity of iron technology in Sulawesi (O'Connor et al. 2014). A significant aspect of this research focuses on the interpretation of changing human economic strategies, and the reconstruction of local and regional environments through time. In this respect, the vertebrate fauna from Gua Sambangoala dated approximately 5500-3500 years ago provides useful new insights into human foraging behaviour during the mid-Holocene in Southeast Sulawesi. In addition, study of the small vertebrate remains that had become inadvertently incorporated into the accumulating cave sediments also provides information on local palaeoecology during periods of human occupation of the rockshelter. 


\section{Gua Sambangoala}

Gua Sambangoala is a rockshelter in Walandawe village, Routa Subdistrict, North Konawe District, Southeast Sulawesi Province. It lies under an overhang in a karst cliff that is long and continuous, and clearly visible from the approach path to the site. The complex surrounding geology includes outcrops of ultramafic ophiolitic rocks, which have been explored for their potential for nickel mining (O'Connor et al. 2014). Gua Sambangoala is located at coordinates $3^{\circ} 1^{\prime} 17.4^{\prime \prime} \mathrm{S} 121^{\circ} 43^{\prime} 12.9^{\prime \prime} \mathrm{E}$ and an elevation of 344 metres above sea level ( $\mathrm{m}$ asl). The entrance is $5 \mathrm{~m}$ long, $2.4 \mathrm{~m}$ high and oriented south. The rockshelter is well illuminated at the entrance but dim towards the rear, where a narrow channel runs. There are no stalactities or stalagmites within the site, and the sediment on the surface is fully dry and rich with freshwater shell remains (Figures 10.1 and 10.2).
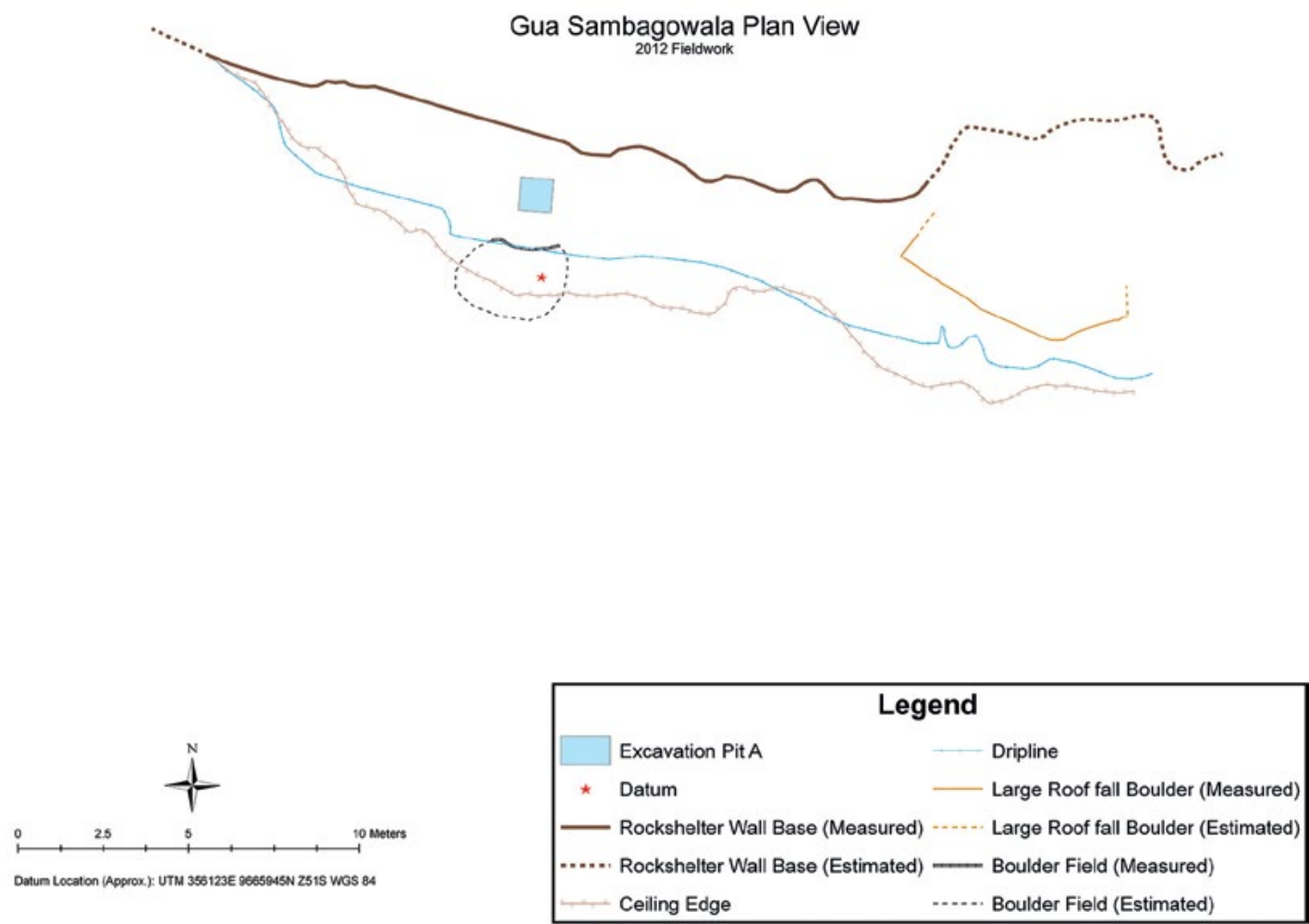

Figure 10.1: Gua Sambangoala site plan.

Source: Original plan by Jack Fenner.

The site is in a valley surrounded by the mountain ranges and hilly karsts of North Konawe. The topography here is predominantly sloping, dissected by steep cliffs. The plants growing in front of and around the rockshelter include scrub (semak belukar) and various other sturdy types such as bamboo and teak. A small stream, a tributary of the Wiwirano River which drains southward into the Lasolo River, passes $50 \mathrm{~m}$ in front of the rockshelter. 


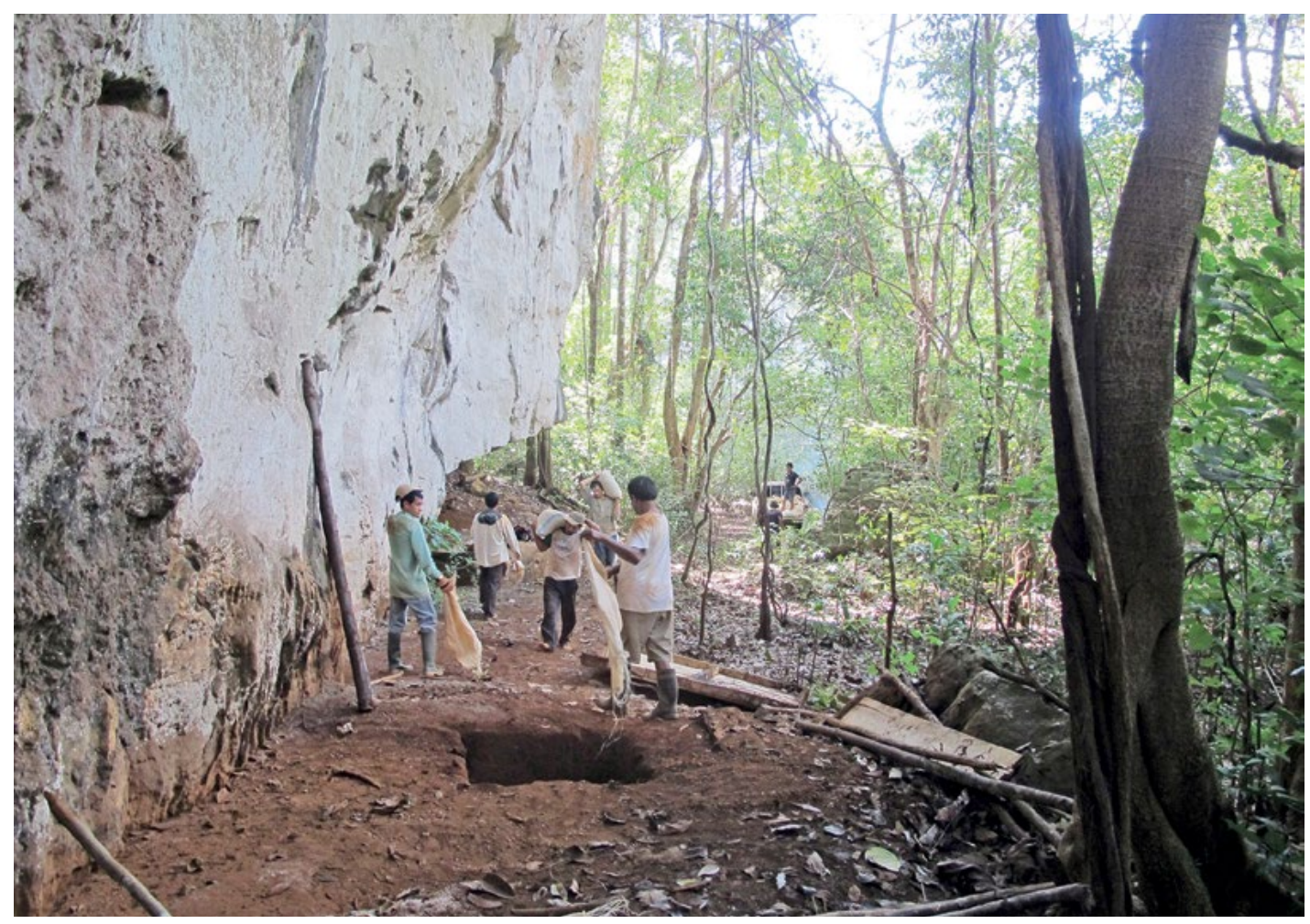

Figure 10.2: Gua Sambangoala site, test pit and approach path.

Source: Photograph by Jack Fenner.

The choice of where to excavate was based on surface-find concentrations of cultural remains. The excavation involved a $1 \mathrm{~m}^{2}$ test pit, called square $\mathrm{A}$, excavated to a depth of $2.4 \mathrm{~m}$. The finds from the excavation include porcelain and earthenware sherds, dammar, a metallic lump that resembles iron slag, bone tools, flaked stone artefacts and stone manuports, baked clay fragments, and charcoal (O'Connor et al. 2014). Seven Accelerator Mass Spectrometry (AMS) dates were obtained on charcoal samples (Table 10.1). The earliest dates of around $5500 \mathrm{cal}$ BP were obtained at a depth of $2.3-2.4 \mathrm{~m}$. All of the dates relate to pre-Neolithic occupation, because pottery was restricted to the top $15 \mathrm{~cm}$. In summary, the archaeological record bracketed by the radiocarbon assays consists of just over $2 \mathrm{~m}$ of cultural deposit dated to between approximately 3500 and $5500 \mathrm{cal} \mathrm{BP}$ (Figure 10.3).

Table 10.1: Gua Sambangoala square A AMS dates, processed by the Accelerator Mass Spectrometry Laboratory (Direct AMS) in Seattle, Washington.

\begin{tabular}{|l|r|r|r|r|}
\hline Submitter ID & Approximate Depth & Direct AMS code & \multicolumn{1}{c|}{ Determination } & $\begin{array}{c}\text { 95\% calibrated } \\
\text { confidence interval* }\end{array}$ \\
\hline Sam A_Spit 4 & $25 \mathrm{~cm}$ & D-AMS 001988 & $3297 \pm 29 \mathrm{BP}$ & $3453-3586 \mathrm{BP}$ \\
\hline Sam A_Spit 10 & $70 \mathrm{~cm}$ & D-AMS 001989 & $3295 \pm 29 \mathrm{BP}$ & $4248-4438 \mathrm{BP}$ \\
\hline Sam A_Spit 20 & $1.3 \mathrm{~m}$ & D-AMS 001990 & $3883 \pm 29 \mathrm{BP}$ & $4235-4418 \mathrm{BP}$ \\
\hline Sam A_Spit 25 & $1.6 \mathrm{~m}$ & D-AMS 001991 & $4766 \pm 31 \mathrm{BP}$ & $5333-5589 \mathrm{BP}$ \\
\hline Sam A_Spit 31 & $2.0 \mathrm{~m}$ & D-AMS 001992 & $4482 \pm 28 \mathrm{BP}$ & $4983-5290 \mathrm{BP}$ \\
\hline Sam A_Spit 37 & $2.3 \mathrm{~m}$ & D-AMS 001993 & $4923 \pm 30 \mathrm{BP}$ & $5597-5715 \mathrm{BP}$ \\
\hline Sam A_Spit 38 & $2.4 \mathrm{~m}$ & D-AMS 001994 & $4802 \pm 26 \mathrm{BP}$ & $5475-5595 \mathrm{BP}$ \\
\hline
\end{tabular}

" Calibrated using 0xCal 4.2 (Bronk Ramsey 2013).

Source: O'Connor et al. (2014). 


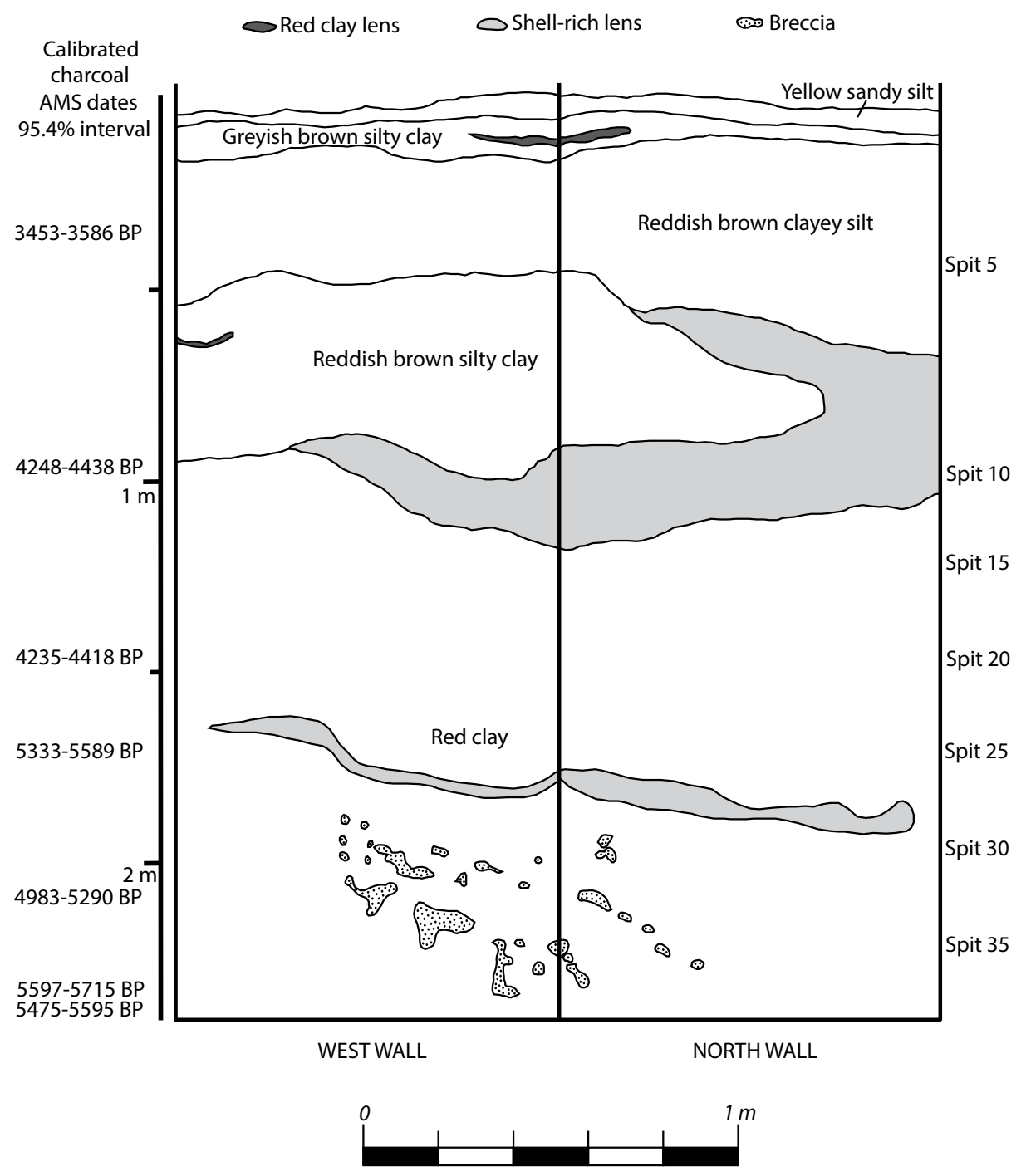

Figure 10.3: Gua Sambangoala stratigraphy and calibrated AMS dates.

Source: Bulbeck et al. (2015).

\section{Background to zooarchaeology in Sulawesi}

Ever since the pioneering research into Indonesia's biogeography by Alfred Russel Wallace, Sulawesi has attracted zoological interest for its diversity of endemic fauna. Groves (1976) identified 100 endemic mammalian species in Sulawesi, while Musser (1987) added 23 species to the list to arrive at a total of 123. Whitten et al. (1987) noted that Sulawesi appeared to have been formed by the collision of splinters of land that had respectively drifted eastward and westward from the Caenozoic continents of Sunda (Southeast Asia) and Sahul (Australia/ New Guinea), but its final location close to Borneo allowed Sunda-based species to raft across to Sulawesi in later times. Accordingly, summarising previous studies, Groves (2001) divided the endemic fauna into two main groups. The first involved the 'old endemics', which included Anoa water buffaloes, Babyroussa and (the now extinct) Celebochoerus suids, Macrogalidia civets, Macaca monkeys, tarsiers, shrews, squirrels, cuscuses and various Muridae amongst other taxa. The second, the 'new endemics', included (inter alia) Sus celebensis, Crocidura nigripes shrews and some rodent species. 
Between the early 19th and mid-20th centuries, there was considerable analysis of faunal remains by archaeologists with the assistance of experts in the natural sciences such as biology, zoology and palaeontology, but this has now evolved into its own methodology, which adds cultural considerations to the natural science foundations (Davis 1987). In the South Sulawesi context, Sarasin and Sarasin (1905) reported on the fauna they had excavated from the Leang Ululeba, Leang Balisao and Leang Cakondo sites, and Hooijer (1950) reported on the faunal assemblages excavated by Dutch colonial archaeologists from the sites of Bola Batu, Panganreang Tudea, Batu Ejjaya and Leang Tomatoa Kacicang. The identified taxa from these assemblages, all undated, included endemic Anoa water buffaloes, and the endemic Sulawesi warty pig (Sus celebensis) and Babyroussa pig-deer, amongst other taxa, as well as the introduced Bubalus bubalis (water buffaloes) and Canidae (dogs).

The subsequent development of radiocarbon allowed South Sulawesi assemblages to be analysed in the context of their chronology. Clason (1976) reported on the mid to late Holocene fauna from the Ulu Leang 1 site, excavated by Ian Glover. It included the Sulawesi warty pig as the taxon most frequently utilised as a probable food source, along with variable quantities of remains from the bear cuscus (Ailurops ursinus), dwarf cuscus (Strigocuscus celebensis), moor macaque (Macaca maura), Anoa (Bubalus depressicornis) and various non-mammalian taxa including tortoises (Coura amboinensis), large snakes (pythons) and a range of small reptiles. Simons and Bulbeck (2004) reported on the late Holocene faunal assemblages excavated by John Mulvaney and R.P. Soejono from the Leang Burung 1, Leang Karassak, and Batu Ejjaya 1 and 2 sites. The identified taxa from these assemblages were similar to those from Ulu Leang 1, except that the introduced rusa deer (Cervus timorensis) replaced Anoa as the identified bovid, and indeed Simons and Bulbeck (2004) developed a hypothesis whereby increased forest disturbance related to human population build-up diminished Anoa numbers but increased the Sus celebensis stock over time.

Subsequent archaeozoological research has extended to the provinces surrounding South Sulawesi. Minanga Sipakko and Kamassi in West Sulawesi, which are open-air sites (unlike the South Sulawesi sites, which are all cave sites), have yielded a faunal assemblage firmly associated with Neolithic habitation and dated to approximately 3500-3000 cal BP. Sus celebensis were abundant throughout the deposits, along with small numbers of Babyroussa remains, but there are also identifications of the introduced Sus scrofa pigs and domestic dogs (Anggraeni et al. 2014). In contrast, the fauna excavated from the Gua Mo'o hono cave Southeast Sulawesi, which is dated between approximately 6500 and $500 \mathrm{cal} \mathrm{BP}$, did not include any identified domesticates, although, as in the West Sulawesi sites, endemic suid identifications were common (O'Connor et al., this volume).

\section{Formulation of the issues}

The previously discussed research into Sulawesi faunal remains has produced a picture of how foragers adapted to their forested environment prior to becoming settled farmers. Unfortunately, apart from the analysis of the Gua Mo'o hono fauna, research on archaeological bone and tooth remains in the northern part of Southeast Sulawesi is limited. The present study aims to complement the Gua Mo'o hono analysis with a similar analysis for Gua Sambangoala. This research began by identifying the local fauna present during the relevant time periods and examining the ways in which people interacted with the fauna in the remote reaches of the Konawe karst ranges. This gave rise to questions such as which types of fauna were known to the Gua Sambangoala occupants, and what was the area's environmental conditions 5500-3500 years ago? Addressing these questions led to an understanding of the adaptations of the local foragers to the variety of mammals within their foraging range during the mid-Holocene. 


\section{Research methods}

\section{Data collection}

The excavation of Gua Sambangoala proceeded using spits of $5 \mathrm{~cm}$ and $10 \mathrm{~cm}$ depths within a $1 \mathrm{~m} \times 1 \mathrm{~m}$ square (Test Pit A), with the deposit sieved using a $1.5 \mathrm{~mm}$ mesh.

\section{Analysis and methods}

The excavated osteological remains were identified to the lowest taxonomic level possible; some of these taxa were as broad as classes and others as narrow as species. My principal guide was the notes I had taken on the metrical and morphological attributes of the teeth, jaws and other bones of Sulawesi forest fauna during my participation in the classification of the Gua Mo'o hono excavated fauna (see Acknowledgements). This identifications work was assisted by the comparative collection at the Makassar Archaeology Office, which included skeletal remains of monkey (Macaca), bear cuscus (Ailurops ursinus), domestic pig (Sus scrofa), fruit bats (Pteropodidae) and birds (Aves). Photographs from the vertebrate collection of the Rijksmuseum voor Natuurlijke Historie in Leiden, Holland, were also consulted.

The analysis utilised summation methods for all the counts of dental and bone specimens that could be identified. The methods most frequently used in zooarchaeology are the Number of Individual Specimens (NISP) and Minimum Number of Individuals (MNI). NISP is the principal method utilised in faunal quantification (O'Connor 2000) and the method used here for comparing the faunal classifications.

Bone weights of the Gua Sambangoala assemblage were also recorded. Bone weights are not useful in comparing the abundance of taxa with each other because the bones of large species weigh much more than the bones of small species. On the other hand, bone weights are useful for stratigraphic and taphonomic analysis because the proportional distribution of element weights across the skeleton is similar across taxa (O'Connor 2000), and so are employed here to supplement the NISP analysis.

The surface condition of the bone was classified as either plain (with no difference in colouration from fresh bone) and discoloured (dark brown to black, resembling heavily burnt bone). When bone fragments were covered by limey concretions, or their surface revealed macrosocopically visible striations (especially those that suggested production of bone tools) or tooth marks, this was also recorded. These and other observations were entered into a Microsoft Excel workbook for analysis.

\section{Results}

\section{Stratigraphic and taphonomic analysis of the Gua Sambangoala square A fauna}

Inspection of the faunal material recorded a count of 7260 fragments weighing $4574.18 \mathrm{~g}$ (Table 10.2). In terms of overall abundance, there were two layers, an upper layer (Spits 1-20) with fewer remains and a lower layer (Spits 21-38) with more abundant remains. Total bone weight ranged between $15.18 \mathrm{~g}$ and $102.00 \mathrm{~g}$ in Spits $1-20$ but between $103.56 \mathrm{~g}$ and $418.03 \mathrm{~g}$ in Spits 21-38. Total NISP indicates a similar division; 34-132 for Spits 1-20 (excluding an outlier of 208) compared with 134-570 for Spits 21-38. The AMS dates (Table 10.1) accordingly indicate a greater quantity of faunal remains deposited between c. 5500-4500 cal BP compared with a smaller quantity between $4500-3500 \mathrm{cal} \mathrm{BP}$. Further, there is little indication that faunal 
abundance was tapering off towards the base of the excavation. For instance, the Spit 36 and Spit 38 total bone weights were respectively the third and fourth largest recorded for any spit, although admittedly the NISP counts of 196 and 166 were less than any NISP count between Spits 21 and 34 (Table 10.2).

Table 10.2: Stratigraphic and taphonomic data on Gua Sambangoala vertebrate remains.

\begin{tabular}{|c|c|c|c|c|c|c|c|c|}
\hline Spit & $\begin{array}{l}\text { Discoloured } \\
\text { fragments } \\
\text { (NISP) }\end{array}$ & $\begin{array}{c}\text { Plain } \\
\text { fragments } \\
\text { (NISP) }\end{array}$ & $\begin{array}{c}\text { Total } \\
\text { fragments } \\
\text { (NISP) }\end{array}$ & $\begin{array}{c}\text { Discoloured } \\
\text { weight (grams), } \\
\text { slightly } \\
\text { weathered }\end{array}$ & $\begin{array}{c}\text { Discoloured } \\
\text { weight (grams), } \\
\text { other }\end{array}$ & $\begin{array}{l}\text { Plain weight } \\
\text { (grams), } \\
\text { slightly } \\
\text { weathered } \\
\end{array}$ & $\begin{array}{c}\text { Plain } \\
\text { weight } \\
\text { (grams), } \\
\text { other }\end{array}$ & $\begin{array}{c}\text { Total } \\
\text { weight } \\
\text { (grams) }\end{array}$ \\
\hline 1 & 16 & 44 & 60 & 4.36 & - & 24.91 & - & 29.27 \\
\hline 2 & 140 & 17 & 157 & 43.88 & - & 8.22 & - & 52.10 \\
\hline 3 & 42 & 7 & 49 & 7.90 & - & 7.28 & - & 15.18 \\
\hline 4 & 42 & 7 & 49 & 11.10 & - & 1.67 & - & 12.77 \\
\hline 5 & 111 & 7 & 118 & 96.96 & 0.22 (SS) & 4.82 & - & 102.00 \\
\hline 6 & 76 & 2 & 78 & 27.80 & - & 0.55 & - & 28.35 \\
\hline 7 & 126 & 4 & 130 & 69.53 & - & 4.43 & - & 73.96 \\
\hline 8 & 199 & 9 & 208 & 86.40 & - & 3.77 & - & 90.17 \\
\hline 9 & 168 & 8 & 176 & 84.34 & $0.28(\mathrm{BT})$ & 3.30 & $3.34(\mathrm{CN})$ & 91.26 \\
\hline 10 & 130 & 2 & 132 & 87.10 & - & 1.46 & - & 88.56 \\
\hline 11 & 141 & 1 & 142 & 79.90 & $\begin{array}{r}0.56(\mathrm{BT}) \\
12.24(\mathrm{CN}) \\
\end{array}$ & 0.74 & - & 93.44 \\
\hline 12 & 33 & 1 & 34 & 22.50 & - & 0.12 & - & 22.62 \\
\hline 13 & 93 & 3 & 96 & 52.71 & - & 0.43 & - & 53.14 \\
\hline 14 & 63 & - & 63 & 47.89 & 0.24 (BT) & - & - & 48.13 \\
\hline 15 & 79 & 1 & 80 & 56.20 & - & 0.08 & - & 56.28 \\
\hline 16 & 66 & 6 & 72 & 44.50 & - & 4.19 & - & 48.69 \\
\hline 17 & 79 & - & 79 & 72.44 & - & - & - & 72.44 \\
\hline 18 & 43 & 3 & 46 & 31.04 & $0.72(\mathrm{BT})$ & 11.72 & - & 43.48 \\
\hline 19 & 75 & - & 75 & 43.12 & - & - & - & 43.12 \\
\hline 20 & 103 & 5 & 108 & 81.22 & $0.44(\mathrm{BT})$ & 1.34 & - & 83.00 \\
\hline 21 & 282 & 4 & 286 & 113.41 & $2.80(\mathrm{CN})$ & 0.61 & - & 116.82 \\
\hline 22 & 564 & 6 & 570 & 221.73 & - & 0.84 & $195.46(\mathrm{CN})$ & 418.03 \\
\hline 23 & 356 & 4 & 360 & 179.75 & - & 0.90 & $0.92(\mathrm{CN})$ & 181.57 \\
\hline 24 & 247 & - & 247 & 103.56 & - & - & - & 103.56 \\
\hline 25 & 435 & 9 & 444 & 167.64 & $0.60(\mathrm{BT})$ & 12.64 & - & 180.88 \\
\hline 26 & 389 & 1 & 390 & 182.40 & - & 3.00 & - & 185.40 \\
\hline 27 & 331 & 1 & 332 & 176.71 & $1.46(\mathrm{BT})$ & 0.58 & - & 178.75 \\
\hline 28 & 414 & 6 & 420 & 277.78 & $15.58(\mathrm{CN})$ & 0.38 & - & 293.74 \\
\hline 29 & 277 & 5 & 282 & 140.27 & 0.28 (SS) & 0.98 & - & 141.53 \\
\hline 30 & 247 & 2 & 249 & 135.59 & $\begin{array}{r}0.24 \text { (SS) } 1.74 \\
\text { (BT) }\end{array}$ & 0.30 & - & 137.87 \\
\hline 31 & 263 & 1 & 264 & 121.06 & - & 0.72 & - & 121.78 \\
\hline 32 & 326 & 2 & 328 & 244.99 & 0.40 (SS) & 3.78 & - & 249.17 \\
\hline 33 & 213 & 3 & 216 & 132.28 & $\begin{array}{r}0.26 \text { (SS) } 1.90 \\
(\mathrm{BT}) 31.40(\mathrm{CN}) \\
\end{array}$ & 0.42 & - & 166.26 \\
\hline 34 & 257 & 2 & 259 & 7.14 & $127.74(\mathrm{CN})$ & - & 0.64 (SS) & 135.52 \\
\hline 35 & 160 & 5 & 165 & 3.61 & $\begin{array}{r}0.18 \text { (SS) } 0.05 \\
\text { (BT) } 133.10(\mathrm{CN})\end{array}$ & 0.18 & $10.94(\mathrm{CN})$ & 148.06 \\
\hline 36 & 190 & 6 & 196 & 25.51 & $\begin{array}{r}0.62(\mathrm{BT}) 232.00 \\
(\mathrm{CN})\end{array}$ & 0.82 & 16.74 (CN) & 275.69 \\
\hline
\end{tabular}




\begin{tabular}{|c|c|c|c|c|c|c|c|c|}
\hline Spit & $\begin{array}{l}\text { Discoloured } \\
\text { fragments } \\
\text { (NISP) }\end{array}$ & $\begin{array}{c}\text { Plain } \\
\text { fragments } \\
\text { (NISP) }\end{array}$ & $\begin{array}{c}\text { Total } \\
\text { fragments } \\
\text { (NISP) }\end{array}$ & $\begin{array}{c}\text { Discoloured } \\
\text { weight (grams), } \\
\text { slightly } \\
\text { weathered }\end{array}$ & $\begin{array}{c}\text { Discoloured } \\
\text { weight (grams), } \\
\text { other }\end{array}$ & $\begin{array}{c}\text { Plain weight } \\
\text { (grams), } \\
\text { slightly } \\
\text { weathered }\end{array}$ & $\begin{array}{l}\text { Plain } \\
\text { weight } \\
\text { (grams), } \\
\text { other }\end{array}$ & $\begin{array}{c}\text { Total } \\
\text { weight } \\
\text { (grams) }\end{array}$ \\
\hline 37 & 132 & 2 & 134 & 3.87 & $\begin{array}{r}0.36 \text { (TM) } 122.78 \\
\text { (CN) }\end{array}$ & - & $2.24(\mathrm{CN})$ & 129.25 \\
\hline 38 & 164 & 2 & 166 & 56.40 & $205.40(\mathrm{CN})$ & 0.54 & - & 262.34 \\
\hline Total & 7072 & 188 & 7260 & 3344.59 & $\begin{array}{r}1.58 \text { (SS) } 8.61 \\
(\mathrm{BT}) 0.36(\mathrm{TM}) \\
883.04(\mathrm{CN})\end{array}$ & 105.72 & $\begin{array}{r}0.64 \text { (SS) } \\
229.64 \text { (CN) }\end{array}$ & 4574.18 \\
\hline
\end{tabular}

SS = surface striation; BT = surface striation interpreted as involved in production of bone tool; $\mathrm{TM}=$ tooth mark; $\mathrm{CN}=$ covered by concretion.

Source: Author's observations.

There was a general tendency for the proportion of discoloured bone to increase with stratigraphic depth (Table 10.2). In terms of NISP counts, this proportion was $27 \%$ in Spit 1, increasing to $86-89 \%$ in Spits $2-4,92-100 \%$ in Spits $5-20$, and $97 \%$ or greater in all deeper spits. The corresponding decrease in the proportion of plain bone with depth can also be shown by referring to the weight of slightly weathered but otherwise plain bone as a proportion of total bone weight. This proportion was $85 \%$ in Spit 1, 16-48\% in Spits 2-3, 0-27\% in Spits 4-18, and just $0-7 \%$ in Spits 19-38. The increased proportion of discoloured bone corresponds to the change from a thin layer of yellow sediment underlain by another thin layer of greyish-brown sediment at the top of the stratigraphic section, underlain in turn by reddish-brown clay until Spit 10 and red clay beneath Spit 10 (Figure 10.3).

Another depth-related phenomenon was the occurrence of strongly adherent dirt concretions on the bone fragments (Table 10.2). These were not recorded for Spits 1-8, before being recorded sporadically for Spits 9-33, and finally coating the majority of the remains (78-97\% by weight) in Spits 34-38. ${ }^{1}$ These concretions were predominantly heavy clay, which reflects the clay sedimentary matrix in the excavated sediment below Spit 10 (Figure 10.3). The concretions were included in the recorded bone weights, which accordingly would be somewhat inflated in the lowest spits.

Concretions would also cover over surface modifications, but their comparative rarity in Spits 1-33 implies that they cannot be treated as the cause for the rarity of surface modifications recorded for the Gua Sambangoala assemblage. As shown in Table 10.2, just $2.22 \mathrm{~g}$ (six specimens, all taxonomically unidentified) were recorded for surface striations that were not attributed to bone-tool manufacture and that accordingly may be evidence for butchery.

Tables 10.3-10.6 present the weights per taxonomic category by spit including whether a proportion or all of the fragments assigned to that category were discoloured. As shown there, the great proportion of the specimens assigned to the 'unidentified mammal' and 'unidentified' categories were discoloured, even in the uppermost spits where the majority of the other faunal remains were plain. As for the categories for the better identified specimens, most of these tended to transition from plain specimens in the higher spits to discoloured specimens in the lower spits, in line with the general increase in the proportion of discoloured remains with stratigraphic depth. A good example is the rat-sized murid category, recorded in small quantities from all except four of the spits; most of its remains in Spits 1-5 were plain, whereas the majority from Spits 6-38 were discoloured. On the other hand, the small proportion of remains from the lowest spits that were plain could often be assigned to a specific taxon, such as the Sus celebensis

1 The predominance of concretions in the lowest spits may well reflect a particularly lengthy period of interment of the remains in the deposit, although the radiocarbon dates (Table 10.1) do not discriminate clearly between Spits 25-33 and Spits 34-38 in terms of antiquity. 
fragments from Spits 35 and 36, and the two identified squirrel fragments (Spits 30 and 38). Overall, the discoloured status of most of the faunal assemblage ( $97 \%$ in terms of NISP count) impacted negatively on the identifiability of the specimens and contributed to the situation whereby 'unidentified' fragments constituted the single largest category ( $79 \%$ by weight; $91 \%$ by NISP count as detailed below).

Table 10.3: Ungulate identifications from Gua Sambangoala (weight in grams).

\begin{tabular}{|c|c|c|c|c|c|c|}
\hline Spit & $\begin{array}{c}\text { Babyroussa } \\
\text { celebensis }\end{array}$ & Sus celebensis & $\begin{array}{c}\text { Babirusa/Celebes } \\
\text { warty pig }\end{array}$ & Deer or bovid & $\begin{array}{c}\text { Bubalus } \\
\text { depressicornis }\end{array}$ & $\begin{array}{c}\text { Unidentified } \\
\text { ungulate }\end{array}$ \\
\hline 1 & - & - & 3.24 & - & - & - \\
\hline 2 & - & - & $4.02^{*}$ & 1.30 & - & - \\
\hline 3 & - & 5.52 & 0.64 & - & - & - \\
\hline 4 & - & - & 2.18 & - & - & - \\
\hline 5 & - & - & $4.30 *$ & - & - & - \\
\hline 6 & - & - & - & - & - & - \\
\hline 7 & - & 3.32 & $2.80^{*}$ & - & - & - \\
\hline 8 & - & 1.30 & 4.30 & - & - & - \\
\hline 9 & - & 3.18 & $1.36^{* t}$ & - & - & - \\
\hline 10 & - & - & $1.52^{*}$ & - & $15.72^{*}$ & - \\
\hline 11 & - & $12.24^{\mathrm{mat}}$ & $1.02^{*}$ & $1.08^{\mathrm{wa}}$ & - & $2.54^{m * n}$ \\
\hline 12 & - & - & - & - & - & - \\
\hline 13 & - & - & $1.34^{* t s}$ & - & - & - \\
\hline \begin{tabular}{|l|}
14 \\
\end{tabular} & - & - & 2.26 & - & - & - \\
\hline 15 & - & 3.28 & - & - & - & - \\
\hline 16 & - & 3.34 & $2.22^{* * t}$ & - & $0.72^{* * t}$ & - \\
\hline 17 & - & 0.80 & - & - & - & - \\
\hline 18 & - & 4.46 & - & - & - & $26.66^{\circ}$ \\
\hline 19 & - & - & $0.92^{* *}$ & - & - & - \\
\hline 20 & - & 0.62 & $0.76^{*}$ & 0.34 & - & - \\
\hline 21 & - & - & $1.40^{*}$ & 0.38 & - & $10.30^{\ldots}$ \\
\hline 22 & - & - & $1.08^{* *}$ & 0.44 & - & 195.46 \\
\hline 23 & - & - & 1.94 & - & - & $10.78^{*}$ \\
\hline 24 & - & - & - & - & - & $6.12^{\text {wat }}$ \\
\hline 25 & - & - & $2.88^{*}$ & - & - & $16.10^{\prime \prime}$ \\
\hline 26 & 0.28 & - & - & - & 20.98 & 0.24 \\
\hline 27 & - & - & $9.52^{* *}$ & - & - & $9.42^{* *}$ \\
\hline 28 & - & - & $30.06^{* *}$ & - & - & - \\
\hline 29 & - & - & - & - & $2.78^{*}$ & $2.92^{* *}$ \\
\hline 30 & - & - & 0.48 & - & - & 8.92 \\
\hline 31 & - & - & $0.62^{* *}$ & - & - & - \\
\hline 32 & - & - & $5.96^{*}$ & - & - & - \\
\hline 33 & - & - & $56.18^{* *}$ & - & - & - \\
\hline 34 & - & - & $1.16^{*}$ & - & - & - \\
\hline 35 & - & 10.94 & $2.26^{*}$ & - & - & - \\
\hline 36 & - & 12.34 & $13.18^{* \prime}$ & - & - & $6.34^{\text {mat }}$ \\
\hline 37 & - & - & 1.66 & $1.64^{* *}$ & - & - \\
\hline 38 & - & 32.48 & $10.98^{* \prime}$ & $6.74 *$ & $2.90^{* * *}$ & - \\
\hline Total & 0.28 & 93.82 & 172.14 & 11.92 & 43.10 & 295.80 \\
\hline
\end{tabular}

"A proportion discoloured." All discoloured. Source: Author's observations. 
The Archaeology of Sulawesi

Table 10.4: Medium-sized mammal identifications from Gua Sambangoala (weight in grams).

\begin{tabular}{|c|c|c|c|c|c|c|}
\hline Spit & Ailurops ursinus & $\begin{array}{l}\text { Strigocuscus } \\
\text { celebensis }\end{array}$ & Масаса sp(p). & Squirrel & $\begin{array}{c}\text { Macrogalidia } \\
\text { musschenbroekii }\end{array}$ & $\begin{array}{c}\text { Unidentified medium- } \\
\text { sized mammal }\end{array}$ \\
\hline 1 & - & - & - & - & - & - \\
\hline 2 & - & - & 0.32 & - & - & - \\
\hline 3 & - & - & - & - & - & - \\
\hline 4 & - & - & - & - & - & - \\
\hline 5 & 0.58 & - & - & - & - & - \\
\hline 6 & - & - & 0.52 & - & - & - \\
\hline 7 & - & - & - & - & - & - \\
\hline 8 & 0.44 & 1.22 & 0.38 & - & - & - \\
\hline 9 & $0.86^{* *}$ & - & $0.62^{*}$ & - & - & - \\
\hline 10 & - & - & $1.18^{* *}$ & - & - & - \\
\hline 11 & - & - & - & - & - & - \\
\hline 12 & - & - & - & - & - & - \\
\hline 13 & - & 0.03 & - & - & - & - \\
\hline 14 & - & - & - & - & - & - \\
\hline 15 & - & $0.18^{* *}$ & - & - & - & - \\
\hline 16 & 0.26 & - & $0.24^{* *}$ & - & $0.27^{*}$ & - \\
\hline 17 & - & $0.18^{*: *}$ & - & - & - & - \\
\hline 18 & - & $0.28 *$ & - & - & - & - \\
\hline 19 & - & - & - & - & - & - \\
\hline 20 & - & - & - & - & - & - \\
\hline 21 & - & - & - & - & - & - \\
\hline 22 & - & $0.33^{*}$ & - & - & - & - \\
\hline 23 & - & - & 0.78 & - & - & - \\
\hline 24 & - & $0.16^{* *}$ & - & - & - & - \\
\hline 25 & - & $0.20^{* *}$ & - & - & - & - \\
\hline 26 & - & 0.14 & - & - & - & - \\
\hline 27 & - & $0.15 *$ & - & - & - & - \\
\hline 28 & - & $0.10^{* *}$ & - & - & 0.05 & - \\
\hline 29 & - & $2.02^{* *}$ & - & - & - & - \\
\hline 30 & - & 0.10 & - & 0.20 & - & - \\
\hline 31 & - & $0.20^{* *}$ & - & - & - & - \\
\hline 32 & - & $3.06^{* *}$ & - & - & - & - \\
\hline 33 & - & $1.38^{* *}$ & - & - & - & - \\
\hline 34 & $0.40^{* *}$ & $1.44^{* t}$ & - & - & - & $0.74^{* * t}$ \\
\hline 35 & - & $1.16^{*}$ & - & - & - & - \\
\hline 36 & - & $2.40^{\circ}$ & $8.08^{*}$ & - & - & - \\
\hline 37 & - & $0.44^{* *}$ & $6.12^{*}$ & - & - & - \\
\hline 38 & $0.16^{* *}$ & - & $3.20 \%$ & 0.02 & - & - \\
\hline Total & 2.70 & 15.17 & 21.44 & 0.22 & 0.32 & 0.74 \\
\hline
\end{tabular}

"A proportion discoloured. "All discoloured.

Source: Author's observations. 
Table 10.5: Other mammal identifications from Gua Sambangoala (weight in grams).

\begin{tabular}{|c|c|c|c|c|c|c|c|}
\hline Spit & Homo & $\begin{array}{l}\text { old World } \\
\text { fruit bat }\end{array}$ & $\begin{array}{c}\text { Insectivorous } \\
\text { bat }\end{array}$ & $\begin{array}{c}\text { Unidentified } \\
\text { bat }\end{array}$ & Rat-sized murid & $\begin{array}{c}\text { Unidentified } \\
\text { small mammal }\end{array}$ & $\begin{array}{c}\text { Unidentified } \\
\text { mammal }\end{array}$ \\
\hline 1 & 1.34 & - & - & - & 0.03 & - & $1.50 \%$ \\
\hline 2 & 2.94 & - & - & - & 0.14 & - & - \\
\hline 3 & - & - & 0.78 & - & 0.34 & - & $0.70 \%$ \\
\hline 4 & - & - & - & - & $0.68^{*}$ & - & 0.20 \\
\hline 5 & - & - & - & - & 0.62 & - & - \\
\hline 6 & - & - & - & - & $0.06 \%$ & - & - \\
\hline 7 & - & - & - & $0.34^{m *}$ & $0.36^{* 1}$ & - & $0.93^{2}$ \\
\hline 8 & - & - & 0.14 & - & $0.68 \%$ & - & $1.26^{\prime \prime}$ \\
\hline 9 & - & - & - & - & 0.64 & - & $0.50^{*}$ \\
\hline 10 & 0.70 & - & - & $0.14 *$ & $0.50^{* \mathrm{*}}$ & - & $5.50^{* 2}$ \\
\hline 11 & - & - & - & - & $0.51^{\mathrm{m}}$ & - & $2.20^{m}$ \\
\hline 12 & - & - & - & - & - & - & $1.10^{m}$ \\
\hline 13 & - & - & - & - & $1.44 *$ & - & 0.50 \\
\hline 14 & - & - & - & - & - & - & $1.10^{*}$ \\
\hline 15 & - & - & - & - & 0.08 & - & $9.90^{\circ}$ \\
\hline 16 & - & - & - & - & $0.54^{* * \mathrm{~s}}$ & - & 1.20 \\
\hline 17 & - & - & $0.16^{* *}$ & - & - & - & 2.50 \\
\hline 18 & - & - & - & - & $0.58^{\circ}$ & - & $0.38^{\mathrm{mat}}$ \\
\hline 19 & - & - & - & - & - & - & - \\
\hline 20 & - & - & - & - & $0.50^{*}$ & - & - \\
\hline 21 & - & - & - & - & $0.65^{*}$ & - & 2.80 \\
\hline 22 & - & - & - & - & $1.34^{*}$ & - & 5.60 \\
\hline 23 & - & 0.12 & - & - & $1.35^{*}$ & - & $1.80^{m}$ \\
\hline 24 & - & - & - & - & 0.36 & - & $3.40^{\mathrm{m}: \mathrm{s}}$ \\
\hline 25 & - & - & $0.40^{* *}$ & - & $3.44^{*}$ & - & $5.30^{\mathrm{m}: \mathrm{s}}$ \\
\hline 26 & - & - & $0.38^{*}$ & - & $4.70^{*}$ & - & $5.70^{\mathrm{m}}$ \\
\hline 27 & 0.58 & - & - & - & $4.62^{*}$ & $0.40^{* * *}$ & $8.00 \%$ \\
\hline 28 & - & 0.08 & - & - & $5.87^{*}$ & - & $9.90 \mathrm{~m}$ \\
\hline 29 & - & - & - & - & $3.74^{*}$ & - & 3.08 \\
\hline 30 & - & - & 0.14 & - & $2.38^{* * t}$ & - & 13.06 \\
\hline 31 & - & - & - & - & $0.72^{*}$ & $0.42^{*}$ & $1.02^{* n}$ \\
\hline 32 & - & - & - & - & $1.74^{* t}$ & - & $0.40^{\ldots *}$ \\
\hline 33 & - & - & - & - & $2.86^{\circ}$ & - & $1.50^{\mathrm{m}}$ \\
\hline 34 & - & - & - & - & $3.22^{* *}$ & - & $0.60^{m:}$ \\
\hline 35 & - & - & - & $0.05 *$ & $0.24^{*}$ & - & $12.90^{\circ:}$ \\
\hline 36 & - & - & - & - & $0.24^{*}$ & - & 3.60 \\
\hline 37 & - & - & - & - & $0.54^{* *}$ & - & 2.28 \\
\hline 38 & - & - & - & - & $0.46^{* *}$ & - & - \\
\hline Total & 5.56 & 0.20 & 2.00 & 0.53 & 46.17 & 0.82 & 110.41 \\
\hline
\end{tabular}

"A proportion discoloured. " All discoloured. Source: Author's observation. 
164 The Archaeology of Sulawesi

Table 10.6: 0ther identifications from Gua Sambangoala (weight in grams).

\begin{tabular}{|c|c|c|c|c|c|c|}
\hline Spit & Fish & Frog/toad & Monitor lizard & Snake & Bird & Unidentified \\
\hline 1 & - & - & - & 1.14 & - & $22.02^{*}$ \\
\hline 2 & - & 1.14 & - & - & 0.14 & $42.10^{*}$ \\
\hline 3 & - & - & - & - & - & 7.20 \\
\hline 4 & - & - & 0.03 & - & $0.38 * n$ & 9.30 w \\
\hline 5 & - & - & - & - & $0.18^{* *}$ & $96.42^{* *}$ \\
\hline 6 & - & $0.77^{*}$ & - & 0.20 & - & $26.80 \%$ \\
\hline 7 & $0.48^{* *}$ & $0.61^{*: *}$ & - & $12.32^{* *}$ & - & $52.80 \%$ \\
\hline 8 & - & $0.62^{m *}$ & - & - & 0.03 & $79.80 \%$ \\
\hline 9 & - & $3.50^{*}$ & - & $4.12^{*}$ & - & $76.48^{*}$ \\
\hline 10 & - & - & - & - & - & $63.30 \%$ \\
\hline 11 & $0.66^{* *}$ & $0.86^{* *}$ & $0.03^{* k}$ & $8.64^{* * t}$ & - & $63.66^{*}$ \\
\hline 12 & 0.12 & 0.20 & - & - & - & $21.20 \%$ \\
\hline 13 & - & $1.50^{*}$ & - & $0.03^{* *}$ & - & $48.30^{\ldots *}$ \\
\hline 14 & - & $0.78^{* *}$ & - & - & $0.05^{* *}$ & $43.94^{* *}$ \\
\hline 15 & - & $0.56^{* *}$ & - & $0.38^{* *}$ & - & $41.90^{* *}$ \\
\hline 16 & - & - & - & - & - & $39.90 \%$ \\
\hline 17 & - & - & - & - & - & $68.80 \%$ \\
\hline 18 & - & - & - & - & - & $11.12^{* *}$ \\
\hline 19 & - & $0.14^{* *}$ & - & - & $0.16^{* t}$ & $41.90^{*}$ \\
\hline 20 & - & $0.64^{\text {wnt }}$ & - & $24.18^{\mathrm{m}}$ & - & $55.96^{\ldots *}$ \\
\hline 21 & 0.16 & $0.03^{\text {*nt }}$ & $0.08^{\text {wan }}$ & $1.16^{\mathrm{*n}}$ & - & $99.86^{\ldots *}$ \\
\hline 22 & - & $1.47^{* *}$ & - & $11.91^{* *}$ & - & $200.40^{\text {wat }}$ \\
\hline 23 & - & $0.32^{\ldots}$ & - & 1.20 & - & 163.28 \\
\hline 24 & - & $1.50^{* * \mathrm{*}}$ & - & - & - & $92.02^{* *}$ \\
\hline 25 & - & $1.26^{*}$ & - & $1.20 \%$ & - & 150.10 : \\
\hline 26 & - & $0.78^{\mathrm{mat}}$ & $0.10^{m+n}$ & - & - & $152.10^{\text {win }}$ \\
\hline 27 & - & $1.16^{* *}$ & - & $26.44^{* *}$ & - & $118.46^{*}$ \\
\hline 28 & - & $1.42^{* *}$ & - & $7.06^{* *}$ & - & 239.20 " \\
\hline 29 & - & $1.79^{* *}$ & - & $0.60 \ldots$ & - & $124.60^{* *}$ \\
\hline 30 & - & $1.00^{* *}$ & - & - & $0.01^{* *}$ & $111.58^{* *}$ \\
\hline 31 & - & $0.38^{* *}$ & - & $1.12^{* *}$ & - & $117.3^{* * t}$ \\
\hline 32 & 0.74 & $1.04^{m *}$ & - & $0.03^{* n}$ & - & 236.20 \\
\hline 33 & - & $0.58 *$ & - & - & - & 103.76 \\
\hline 34 & - & - & - & $1.82^{* n}$ & - & 126.14 \\
\hline 35 & - & - & - & $5.88^{*}$ & - & $114.63^{*: t}$ \\
\hline 36 & - & - & - & $0.49^{* *}$ & - & $229.02^{* *}$ \\
\hline 37 & - & $0.51^{* *}$ & - & $0.10^{\ldots *}$ & - & $115.96^{*}$ \\
\hline 38 & - & - & - & - & - & $205.40^{*}$ \\
\hline Total & 2.16 & 24.56 & 0.24 & 110.02 & 0.95 & 3612.91 \\
\hline
\end{tabular}

"A proportion discoloured." All discoloured.

Source: Author's observations. 


\section{Faunal variation at the Gua Sambangoala site, square A}

The 7260 fragments bone and tooth fragments included eight fragments $(0.1 \%)$ identified as human, 528 other fragments $(7.3 \%)$ classifiable to various taxonomic levels, and a further 126 fragments (1.7\%) sufficiently intact to be classified to the 'small mammal', 'medium-sized mammal' and 'mammal' categories (see Figure 10.4). The remaining fragments (90.9\%) were too fragmentary for even these high-level classifications to be applied. Mammals (notably rats and suids) dominate the faunal identifications, but small to medium numbers of birds, reptiles, amphibians and fish were also identified (see Table 10.7).

The identified human remains (all plain) were concentrated in the top two spits (Table 10.5), and these subsurface specimens probably derive from ethnohistorical mortuary disposals at the site (see O'Connor et al. 2014). Otherwise, it is very difficult to see any patterning in the stratigraphic distribution of the identifications, particularly when the increased abundance of faunal material below Spit 20 is taken into account. For instance, suid identifications were made for every spit except Spits 6, 12 and 29 (Table 10.3), similar to the identification of rats throughout the sequence. As another example, Sulawesi dwarf cuscus identifications were made for just five of the upper 20 spits, which are characterised by a relatively small faunal assemblage overall, but for 15 of the lower 18 spits (Table 10.4). ${ }^{2}$ In summary, the Gua Sambangoala square A faunal assemblage is best treated as stratigraphically unpatterned in terms of taxonomic composition, with the proviso that the low proportion of identifications combined with their diversity hinders stratigraphic discrimination.

The high proportion of discoloured fragments noted above applies virtually across the faunal spectra, including the main microfauna categories of rats (90/145 NISP, 62\%) and frogs/toads (77/88 NISP, 87.5\%). Accordingly, discoloured compared with plain status is unlikely to reflect cooking of the animal but instead the post-depositional effects. At the Tron Bon Lei site in Alor, the fragments of small vertebrates such as rats revealed traces of owl digestion but were also often blackened, either burnt through incidental exposure to hearth fires and/or manganesestained (Hawkins et al. 2018). To extend this observation to Gua Sambangoala, its discoloured vertebrate fragments may also have been incorporated within hearths. Although there were no red clay lenses (probable hearth features) in the stratigraphic section below Spit 8 (Figure 10.3), the reddish to red clay matrix at greater depths, combined with the increased proportion of burnt remains, may reflect successive hearth-formation events that made it difficult for the excavators to identify individual hearth features. Alternatively, traces of heavy metal in the sediment (as perhaps reflected in the metallic lump that resembles iron slag, noted above) may have been the main discolouration agent.

The frog/toad, insectivorous bat and an unknown proportion of the rat remains at Gua Sambangoala may reflect non-human rather than human predation, or even the use of the rockshelter as a dwelling place. Naturally occurring predators on Sulawesi include civets, snakes and varanids (all found amongst the faunal remains) as well as various birds of prey. Sulawesi's murids include large forest rats, fully suitable for human consumption, as well as a plethora of small rats (Musser 1987); unfortunately, identification of the Gua Sambangoala rat specimens to species was not possible. Similarly, observations of tooth marks (one fragment) and possible cut marks (six fragments, none taxonomically identified) were too infrequent to provide an insight into the non-human versus the human contribution to the faunal assemblage. Overall, in view of

2 Differences between the spits in their quantity of the Sulawesi dwarf cuscus can be largely attributed to the quantity of recovered bone overall, as shown by the Pearson-r correlation coefficients of 0.41 between the dwarf cuscus and total bone weights and 0.37 between the dwarf cuscus and total bone NISP counts. 
the distribution of small quantities of microfauna throughout the assemblage (Tables 10.5 and 10.6), it is likely that the human denizens alternated their presence with non-human predators throughout the recorded occupation sequence.

In addition to rats and anurans, the faunal remains that were represented at the site include snakes, middle-sized mammals (e.g. cuscus and macaques) and suids, as well as various other types of fauna that have a tropical rainforest habitat (Figure 10.4; Table 10.7). The local suids, the babirusa and the Sulawesi warty pig, made up the major portion of the large mammals included in the Gua Sambangoala diet. Their remains were often difficult to tell apart, which may explain why babirusa was much less frequently identified than Sus celebensis at Gua Sambangoala, whereas it was more frequently identified than Sus celebensis at Gua Mo'o hono (O'Connor et al., this volume). In any case, suids may have had larger population numbers in the Walandawe region than any other large mammal (notably the Anoa) at the time. While the variety of faunal identifications associated with the Gua Sambangoala foragers indicates a broadspectrum hunting strategy, ranging from forest rats (potentially) to Anoa, the large size of the suids compared with most of the other identified animals suggests that they constituted the major source of animal protein.

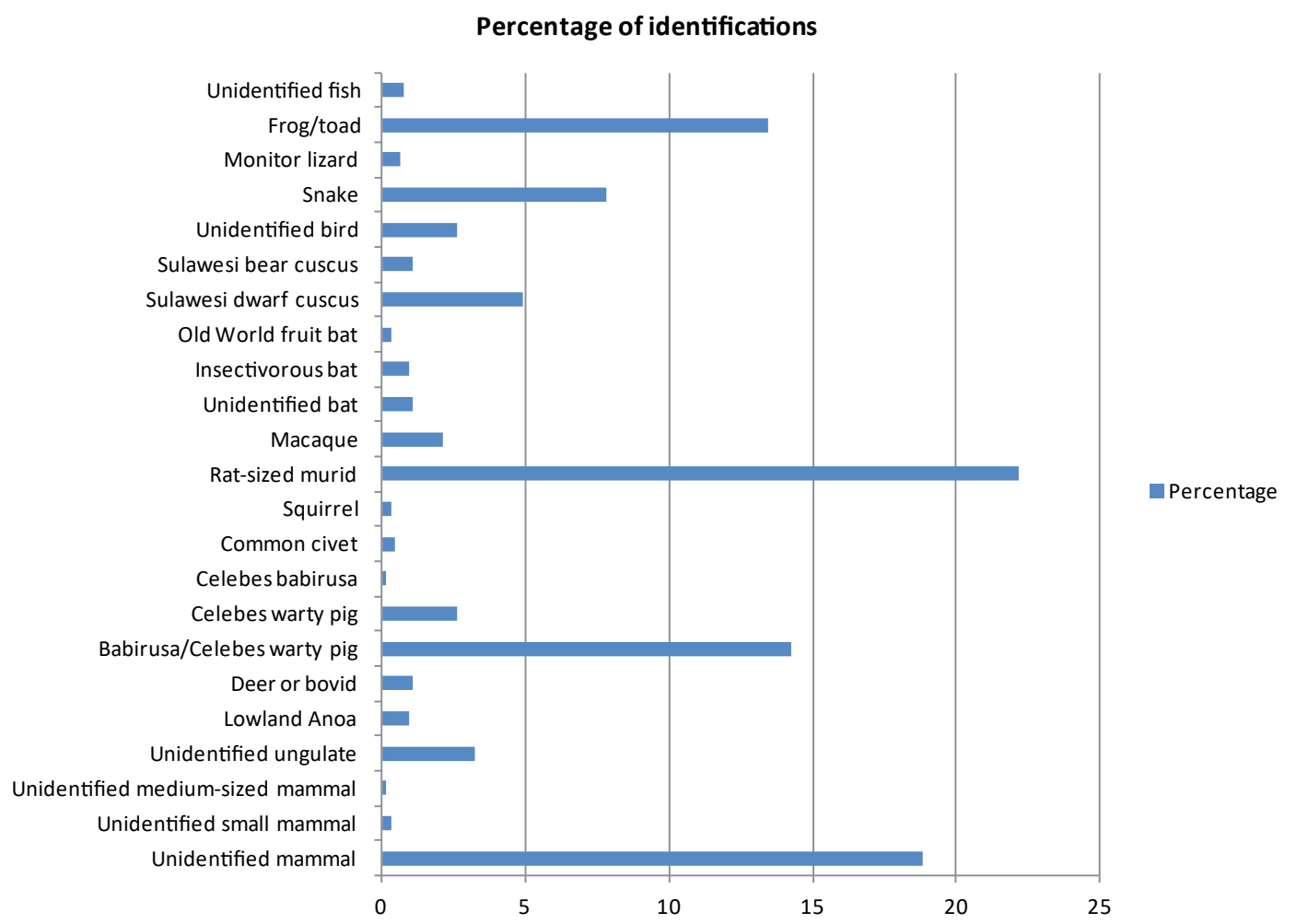

Figure 10.4: Percentages of the NISP identification at Gua Sambangoala.

Source: Author's analysis. 
Table 10.7: Counts of taxonomic identifications from the bone fragments and teeth from the Gua Sambangoala excavation.

\begin{tabular}{|c|c|c|c|c|c|c|}
\hline Class & Order & Family & Taxon & Common name & NISP & MNI \\
\hline Osteichthyes & & & & Fish & 5 & 1 \\
\hline Amphibia & Aпuгa & & & Frog/Toad & 88 & 15 \\
\hline \multirow[t]{2}{*}{ Reptiles } & Squamata & Varanidae & Varanus sp(p). & Monitor lizard & 4 & 1 \\
\hline & & Serpentes (suborder) & & Snake & 51 & 1 \\
\hline Aves & & & & Unidentified bird & 17 & 1 \\
\hline \multirow[t]{18}{*}{ Mammalia } & Diprotodontia & Phalangeridae & Ailurops ursinus & Sulawesi bear cuscus & 7 & 1 \\
\hline & & & $\begin{array}{l}\text { Strigocuscus } \\
\text { celebensis }\end{array}$ & $\begin{array}{l}\text { Sulawesi dwarf } \\
\text { cuscus }\end{array}$ & 32 & 9 \\
\hline & & Pteropodidae & & old World fruit bat & 2 & 1 \\
\hline & & Yangochiroptera (suborder) & & Insectivorous bat & 6 & 2 \\
\hline & Chiroptera & & & Unidentified bat & 7 & 1 \\
\hline & Primates & Cercopithecidae & Macaca sp(p). & Macaque & 14 & 2 \\
\hline & Rodentia & Muridae & & Rat-sized murid & 145 & 24 \\
\hline & & Sciuridae & & Squirrel & 2 & 1 \\
\hline & Carnivora & Viverridae & $\begin{array}{l}\text { Macrogalidia } \\
\text { musschenbroekii }\end{array}$ & Sulawesi palm civet & 3 & 3 \\
\hline & Artiodactyla & Suidae & $\begin{array}{l}\text { Babyroussa } \\
\text { celebensis }\end{array}$ & Sulawesi babirusa & 1 & 1 \\
\hline & & & Sus celebensis & Celebes warty pig & 17 & 7 \\
\hline & & Suidae & & $\begin{array}{l}\text { Babirusa/Celebes } \\
\text { warty pig }\end{array}$ & 93 & 22 \\
\hline & & Bovinae & & Deer or bovid & 7 & 1 \\
\hline & & & $\begin{array}{l}\text { Bubalus } \\
\text { depressicornis }\end{array}$ & Lowland Anoa & 6 & 2 \\
\hline & & & & Unidentified ungulate & 21 & - \\
\hline & & & & $\begin{array}{l}\text { Unidentified medium- } \\
\text { sized mammal }\end{array}$ & 1 & - \\
\hline & & & & $\begin{array}{l}\text { Unidentified small } \\
\text { mammal }\end{array}$ & 2 & - \\
\hline & & & & Unidentified mammal & 123 & - \\
\hline \multicolumn{5}{|l|}{ TOTAL } & 654 & 96 \\
\hline
\end{tabular}

Source: Author's analysis.

\section{Condition of the Gua Sambangoala environment at 5500-3500 BP}

There are unlikely to have been significant changes in the limestone karst and surrounding environments of Gua Sambangoala between the mid-Holocene and the present. The types of fauna identified from the site suggest an environment with a mosaic of open grasslands, woodland and rainforest. While we cannot be specific about which of these components would have been the focus of the Gua Sambangoala occupants, it can nonetheless be inferred that their protein data included terrestrial resources and aquatic resources in the form of fish, probably from local nearby rivers and streams. The site also contained significant quantities of freshwater shellfish, which do not form part of the present study. Identification of the rat remains to species level, which may be possible in the future, may provide a better insight into the diversity of habitat catchments near the site, as well as environmental change over time. 


\section{Conclusion}

The Gua Sambangoala square A faunal assemblage was predominantly deposited between c. 5500-4500 cal BP (Spits 21-38) and a minor proportion between c. 4500-3500 cal BP (Spits 1-20). Taphonomic alterations to the bone, however, varied according to a different pattern. Only in Spit 1 did the quantity of plain bone exceed the quantity of discoloured bone, and by Spit 5 (and below) the proportion of plain bone was almost negligible. The predominance of discoloured bone, which can be attributed to incidental exposure to heat and/or metallic staining rather than cooking practices, contributed to the high proportion of the assemblage ( $91 \%$ by NISP count) being classified as 'unidentified'. Another taphonomic phenomenon, the incidence of concretions on the bone remains, was recorded sporadically between Spits 9 and 33 but coated the majority of the remains in Spits 34 to 38.

During the period covered by the radiocarbon dates the fauna available to the rockshelter occupants included fish, anurans, lizards, snakes, birds, bear cuscus and Sulawesi dwarf cuscus, bats, monkeys, rats, squirrels, civet cats, pig-deer (babirusa), Sulawesi warty pig (Sus celebensis) and Anoa. No clear evidence could be found for change in the composition of the fauna over time, notwithstanding the caveat that the great majority of the remains could not be identified with any specificity. One apparent feature of the assemblage is a greater representation of suids than Anoa; this may reflect greater ease of hunting in more open habitats, which are attractive to suids, rather than the thickly forested habitats preferred by Anoa (Simons and Bulbeck 2004). Accordingly, the environment of the Gua Sambangoala site between 5500 and 3500 years ago was probably not very different from the present environment.

\section{Acknowledgements}

The author acknowledges funding assistance from the Australian Research Council for its Discovery Project grant DP110101357 'The Archaeology of Sulawesi: A strategic island for understanding modern human colonization and interactions across our region' (awarded to Sue O'Connor, Jack Fenner, Janelle Stevenson and Ben Marwick). This assistance funded the author's participation in the classification of the Gua Mo'o hono excavated faunal assistance at The Australian National University in Canberra (under the supervision of Ken Aplin) and the Makassar Archaeology Office (under the supervision of Philip Piper, who also assisted the author with access to photographs from the Risksmuseum voor Natuurlijke Historie vertebrate collection). This assistance also funded classificatory work on the Gua Sambangoala fauna by the author (assisted by Jamil, then an archaeology student at Hasanuddin University in Makassar). The valuable comments by two anonymous referees are also gratefully acknowledged.

\section{Author biography}

Fakhri Makassar Archaeology Office, Makassar, South Sulawesi, Indonesia

\section{References}

Anggraeni, T. Simanjuntak, P. Bellwood and P. Piper. 2014. Neolithic foundations in the Karama valley, West Sulawesi, Indonesia. Antiquity 88:740-756. doi.org/10.1017/S0003598X00050663 (accessed 5 June 2018).

Bronk Ramsey, C. 2013. OxCal 4.2 manual. c14.arch.ox.ac.uk/oxcal/OxCal.html (accessed 27 October 2018). 
Bulbeck, D., S. O'Connor and Fakhri. 2015. Decorated and plain baked clay from the initial to the late Holocene at Gua Talimbue, Southeast Sulawesi, Indonesia. Presentation at the 15 th International Conference of the European Association of Southeast Asian Archaeologists, Paris, 6-10 July.

Clason, A.T. 1976. A preliminary note about the animal remains from the Leang 1 cave, South Sulawesi, Indonesia. Modern Quaternary Research in Southeast Asia, pp. 53-57. Modern Quaternary Research in Southeast Asia, Volume 2. Rotterdam: A.A. Balkema.

Davis, S.J.M. 1987. The Archaeology of Animals. London: B.T. Batsford.

Groves, C.P. 1976. The origin of the mammalian fauna of Sulawesi (Celebes). Zeitschrift für Sängetierkunde 41:201-216.

Groves, C.P. 2001. Mammals in Sulawesi: Where did they come from and when, and what happened to them when they got there? In I. Metcalfe, J. Smith, M. Morwood and I. Davidson (eds), Faunal and Floral Migrations and Evolution in SE Asia-Australasia, pp. 332-342. Lisse: A. A. Balkema.

Hawkins, S., S.C. Samper Carro, J. Louys, K. Aplin, S. O'Connor and Mahirta. 2018. Human palaeoecological interactions and owl roosting at Tron Bon Lei, Alor Island, eastern Indonesia. The Journal of Island and Coastal Archaeology 13(3):371-387. doi.org/10.1080/15564894.2017.128 5834 (accessed 5 June 2018).

Hooijer, D.A. 1950. Man and Other Mammals from Toalian Sites in south-western Celebes. Verhandelingen der Koninklijke Nederlandse Akademie van Wetenschappen, Afd. Natuurkunde. Amsterdam: NorthHolland Publishing Co.

Musser, G. 1987. The mammals of Sulawesi. In T.C. Whitmore (ed.), Biogeographical Evolution of the Malay Archipelago, pp. 73-93. Oxford: Clarendon Press.

O’Connor, S., F.A. Aziz, B. Marwick, J. Fenner, B. Prasetyo, D. Bulbeck, T. Maloney, E.S. Pierre, R. Whitau, U.P. Wibowo, B. Hakim, A. Calo, Fakhri, M. Husni, Hasanuddin, A.A. Oktaviana, D. Prastiningtyas, F.Z. Campos, and P.J. Piper with an appendix by A.A. Oktaviana and Suryatman. 2014. The Archaeology of Sulawesi: A Strategic Island for Understanding Modern Human Colonization and Interactions Across our Region. Final Report to Indonesia's Bureau of Research and Technology, Department of Archaeology and Natural History, The Australian National University, Canberra and Department of Prehistory, Indonesia’s National Centre for Archaeological Research and Development, Jakarta.

O’Connor, S., D. Bulbeck, P.J. Piper, F. Aziz, B. Marwick, F. Campos, J.N. Fenner, K. Aplin, Fakhri, Suryatman, T. Maloney, B. Hakim and R. Wood. 2018. The human occupation record of Gua Mo'o hono shelter, Towuti-Routa region of Southeastern Sulawesi. In S. O'Connor, D. Bulbeck and J. Meyer (eds), The Archaeology of Sulawesi: Current Research on the Pleistocene to the Historic Period, pp. 117152. Canberra: ANU Press.

O'Connor, T. 2000. The Archaeology of Animal Bones. Stroud, Gloucestershire: Sutton Publishing.

Sarasin, P. and F. Sarasin. 1905. Versuch einer Anthopologie der Insel Celebes. Erster Teil: Die Toála-höhlen von Lamontjong. (Materialien zur Naturgeschichte der insel Celebes, V Band, 1 Teil). Wiesbaden: C.W. Kriedel's Verlag.

Simons, A.G. and D. Bulbeck. 2004. Late Quaternary faunal successions in South Sulawesi, Indonesia. In S.G. Keates and J.M. Pasveer (eds), Quaternary Research in Indonesia Asia, pp. 167-189. Quaternary Research in Southeast Asia, Volume 18. Leiden: A.A. Balkema.

Whitten, A.J., M. Mustafa and G.S. Henderson. 1987. The Ecology of Sulawesi. Yogyakarta: Gadjah Mada University Press. 
This text is taken from The Archaeology of Sulawesi: Current Research on the Pleistocene to the Historic Period, edited by Sue O'Connor, David Bulbeck and Juliet Meyer, published 2018 by ANU Press, The Australian National University, Canberra, Australia.

doi.org/10.22459/TA48.11.2018.10 